\title{
Novel D- $\pi-A$ dye sensitizers of polymeric metal complexes with triphenylamine derivatives as donor for dye-sensitized solar cells: synthesis, characterization and application
}

\author{
GUIPENG TANG, JUN ZHOU, WEI ZHANG, JIAOMEI HU, DAHAI PENG, QIUFANG XIE \\ and CHAOFAN ZHONG*
}

Key Laboratory of Environmentally Friendly Chemistry and Applications of Ministry of Education, College of Chemistry, Xiangtan University, Xiangtan, Hunan 411105, China

MS received 10 February 2014

\begin{abstract}
Because of being the key component of dye-sensitized solar cells and acting as an important role, dye sensitizer and its synthesis and application has been extensively researched. In this paper, four novel polymeric metal complexes with $\mathrm{D}-\pi-\mathrm{A}$ structure that use 4-(octyloxymethyl)-N,N-diphenylbenzenamine as donor group (D), $\mathrm{C}=\mathrm{N}$ bond as a $\pi$-conjugation linkage $(\pi)$, and transition metal complexes as an acceptor (A), were functionally designed and synthesized. All the four polymeric metal complexes exhibited some photovoltaic performance, the highest photoelectric conversion efficiency of compound $\mathrm{P} 4$ reached $1.09 \%\left(J_{\mathrm{sc}}=2.55 \mathrm{~mA} \mathrm{~cm} \mathrm{c}^{-2}, V_{\mathrm{oc}}=0.61 \mathrm{~V}\right.$ and $\mathrm{FF}=70.14 \%$ ) under simulate AM $1.5 \mathrm{G}$ solar irradiation. A new path for the synthesis and study of the dye sensitizer was provided.
\end{abstract}

Keywords. Transition metal; dye sensitizer; polymeric metal complex; triphenylamine; dye-sensitized solar cells.

\section{Introduction}

Among environmently friendly and renewable sources of energy, solar cells have always been high on the list of likely candidates. ${ }^{1}$ Nanocrystalline semiconductor films, in particular of $\mathrm{TiO}_{2}$, have been proven to be a critical component in dye-sensitized solar cells (DSSCs) owing to their transparency, high surface area and unique electronic properties. DSSCs have significant potential as a low-cost alternative to conventional $p-n$ junction solar cells. ${ }^{2}$ The majority of DSSCs use Ru-based complexes (e.g., N3, N719 and black dye), as sensitizers of $\mathrm{TiO}_{2}$, offering an adequate conversion efficiency of light to electricity and a good stability. The most efficient Ru-based DSSC has reached an efficiency of $10-11 \%$ under AM 1.5 irradiation. ${ }^{3}$ Up to now, DSSCs based on metal-free organic dyes, ${ }^{4,5}$ porphyrin dyes, ${ }^{6,7}$ metal-phthalocyanine ${ }^{8}$ and natural dyes ${ }^{9,10}$ have been developed and reported. Among them the generation of donor- $\pi$-conjugation-linkage-acceptor $(\mathrm{D}-\pi-\mathrm{A})$ sensitizers are impressive and encouraging, because $\mathrm{D}-\pi-\mathrm{A}$ structure can help to extend absorption spectra of the dyes, increase the optical absorption coefficient, adjust the highest occupied molecular orbital (HOMO) and lowest unoccupied molecular orbital (LUMO) energy levels. When the acceptors or the donor groups, or the linkers between both, are modified, the absorption can be shifted towards the red part of the solar spectrum, which is a future requirement for highperformance DSSCs that should harvest most of the visible

\footnotetext{
*Author for correspondence (zhongcf798@aliyun.com)
}

and also near-infrared (IR) photons in the solar spectrum. ${ }^{11}$ Efficient charge transfer occurs after anchoring of the sensitizer through a carboxylate group onto the surface of the $\mathrm{TiO}_{2}$ semiconductor. ${ }^{12}$

The high cost and rarity of the ruthenium metal may restrain their extensive applications. So, great efforts have been made to replace Ru-based dyes with metal-free organic dyes, ${ }^{13}$ such as phenothiazine, ${ }^{14}$ indoline, ${ }^{15}$ fluorene, ${ }^{16}$ triarylamine, ${ }^{17}$ thiophene, ${ }^{18,19}$ carbazole ${ }^{20,21}$ and so on. However, the disadvantages of small organic dye molecules are their poor charge transport properties due to the small $\pi$-conjugated system, and their poor chemical stability, light stability, especially the thermal stability because of small molecular weight. Hence, finding cheap substitute metals and macromolecular structure seems very important. As a kind of the plurality of polymers, polymeric metal complexes have received considerable attention for these hybrid materials providing outstanding physical and chemical properties of both organic and inorganic components, such as unique process ability and easy film-forming ability of polymer, prominent luminescence efficiency and good thermal stability of metal. ${ }^{22,23}$ Although the synthesis of polymeric metal complexes has been widely reported, articles about their application in DSSCs are quite limited. Therefore, it is worth synthesizing new polymeric metal complexes and studying their photovoltaic properties.

In this paper, four novel polymeric metal complexes were functionally designed, synthesized and characterized by IR, ${ }^{1} \mathrm{H}$ NMR, gel permeation chromatography (GPC), elemental analysis and so on. A series of $\mathrm{D}-\pi-\mathrm{A}$ polymeric 


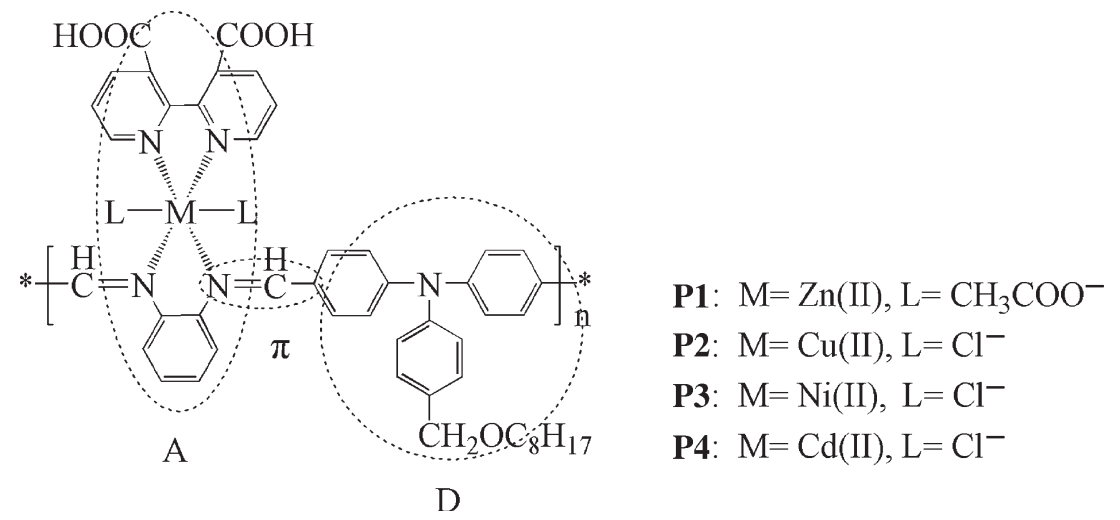

Scheme 1. Chemical structures of P1, P2, P3 and P4.

metal complexes that use 4-(octyloxymethyl)-N,Ndiphenylbenzenamine as donor group (D), $\mathrm{C}=\mathrm{N}$ bond as a $\pi$-conjugation linkage and transition metal complexes as an acceptor (A) have been synthesized and used as sensitizers in the DSSCs. Their chemical structures (P1, P2, P3 and P4) are shown in scheme 1. What is more, their thermal properties, optical properties, photovoltaic properties and electrochemical properties in DSSC were also investigated.

\section{Experimental}

\subsection{Materials}

o-Phenylenediamine, 2,2'-bipyridine-3,3'-dicarboxylic acid, triphenylamine, sodium borohydride and sodium hydride were obtained from Aldrich Chemical Co. and used as received. $\mathrm{N}, \mathrm{N}$-dimethylformamide was dried by distillation over $\mathrm{CaH}_{2}$, methanol was dried over molecular sieves and freshly distilled prior to use, tetrahydrofuran was dried by distillation over sodium. The other materials were common commercial grade and used as received. All chemicals used were of an analytical grade. Solvents were purified with conventional methods.

\subsection{Instrument and measurements}

${ }^{1} \mathrm{H}$ NMR were performed in $\mathrm{CDCl}_{3}$ and recorded on a Bruker Avance 400 spectrometer. GPC analyses were measured by a WATER 2414 system equipped with a set of $\mathrm{HT}_{3}, \mathrm{HT}_{4}$ and $\mathrm{HT}_{5}$, l-styrayel columns with tetrahydrofuran (THF) as eluent and polystyrene as standard. The Fourier transform infrared (FT-IR) spectra were obtained on a Perkin-Elmer Spectrum One Fourier transform infrared spectrometer by incorporating samples in $\mathrm{KBr}$ pellets. Thermogravimetric analyses (TGA), differential scanning calorimetry (DSC) and elemental analysis were performed on Shimadzu TGA-7 Instrument, Perkin-Elmer DSC-7 thermal analyzer and Perkin-Elmer 2400 II instrument, respectively. UV-Visible (UV-Vis) spectra of all the polymers were taken on a Lambda 25 spectrophotometer. Photoluminescent (PL) spectra were taken on a Perkin-Elmer LS55 luminescence spectrometer with a xenon lamp as the light source. Cyclic voltammetry (CV) was conducted on a CHI630C Electrochemical Workstation using a three-electrode system, in a $\left[\mathrm{Bu}_{4} \mathrm{~N}\right] \mathrm{BF}_{4}(0.1 \mathrm{M})$ $\mathrm{N}, \mathrm{N}$-dimethylformamide (DMF) solution at a scan rate of $50 \mathrm{mV} \mathrm{s}^{-1}$. A glassy carbon rod, a Pt wire electrode and a saturated calomel electrode (SCE) were used as working electrode, auxiliary electrode and reference electrode, respectively.

\subsection{Synthesis}

2.3a Synthesis of 4-(N,N-diphenylamino)benzaldehyde (1): In total, $5.00 \mathrm{~g}(20.38 \mathrm{mmol})$ of triphenylamine was reacted with $40.0 \mathrm{ml}$ of DMF in the presence of $15.0 \mathrm{ml}$ of phosphorus oxychloride $\left(\mathrm{POCl}_{3}\right)$ by mixing the first two reactants and adding the latter dropwise with stirring while cooling the reaction vessel in an ice bath. ${ }^{24}$ The mixture was refluxed for about $1 \mathrm{~h}$, then poured into ice-water, neutralized with $40 \%$ sodium hydroxide $(\mathrm{NaOH})$, and the product was obtained by filtration. The crude product was purified through column chromatography on silica gel using chloroform/petroleum benzine (1:3, v/v) as eluent. Bright yellow crystals with yield $80 \%$ (4.46 g) and m.p. $130-131^{\circ} \mathrm{C}$ were obtained. FT-IR (KBr, 4000-450 cm $\left.{ }^{-1}\right): 3037$ (=C-H), 2740 (formyl C-H), $1690(\mathrm{C}=\mathrm{O}) .{ }^{1} \mathrm{H} \mathrm{NMR}\left(400 \mathrm{MHz}, \mathrm{CDCl}_{3}\right) \delta$ (p.p.m.): 9.84 (1H, s), $7.70(2 \mathrm{H}, \mathrm{d}), 7.37(4 \mathrm{H}, \mathrm{q}), 7.22(2 \mathrm{H}$, d), $7.20(2 \mathrm{H}, \mathrm{q}), 7.04(4 \mathrm{H}, \mathrm{d})$.

2.3b Synthesis of [4-(diphenylamino)phenyl]methanol (2): [4-(Diphenylamino)phenyl]methanol 2 was synthesized by reduction of 1 with sodium borohydride $\left(\mathrm{NaBH}_{4}\right)$. In total, $0.29 \mathrm{~g}(7.66 \mathrm{mmol})$ of $\mathrm{NaBH}_{4}$ dissolved in $15.0 \mathrm{ml}$ of aqueous $0.1 \mathrm{M} \mathrm{NaOH}$ solution was added dropwise into $4.01 \mathrm{~g}$ (14.67 mmol) of $\mathbf{1}$ in $50.0 \mathrm{ml}$ of ethanol. ${ }^{25}$ The mixture was reacted at room temperature for $4 \mathrm{~h}$. The solution was extracted with $\mathrm{CH}_{2} \mathrm{Cl}_{2}-\mathrm{H}_{2} \mathrm{O}$, dried with magnesium sulphate $\left(\mathrm{MgSO}_{4}\right)$ and then rotary evaporated. Recrystallization with dichloromethane-hexane gave a white solid. The yield was $85 \%$ (3.43 g). FT-IR (KBr, $\left.4000-450 \mathrm{~cm}^{-1}\right): 3432$ 
$(\mathrm{O}-\mathrm{H}), 3032(=\mathrm{C}-\mathrm{H}), 2930,2877(\mathrm{C}-\mathrm{H}) .{ }^{1} \mathrm{H}$ NMR $(400 \mathrm{MHz}$, $\left.\mathrm{CDCl}_{3}\right) \delta$ (p.p.m.): 7.27-7.02 (14H, m), 4.67 (2H, s), 2.08 $(1 \mathrm{H}, \mathrm{s})$. Anal. calcd for $\mathrm{C}_{19} \mathrm{H}_{17} \mathrm{NO}: \mathrm{C}, 82.88 ; \mathrm{H}, 6.22 ; \mathrm{N}$, 5.09; O, 5.81; Found: C, 82.72; H, 6.24; N, 5.14\%.

$2.3 \mathrm{c}$ Synthesis of 4-(octyloxymethyl)-N,N-diphenylbenzenamine (3): A flask was charged with a mixture of 2 $(2.00 \mathrm{~g}, 7.26 \mathrm{mmol})$, 1-bromooctane $(1.45 \mathrm{~g}, 7.51 \mathrm{mmol})$, sodium hydride $(\mathrm{NaH})(0.53 \mathrm{~g}, 22.08 \mathrm{mmol})$ and $\mathrm{THF}$ $(50 \mathrm{ml})$. Then the flask was pumped into vacuum and purged with $\mathrm{N}_{2}$. The mixture was reacted at room temperature for $24 \mathrm{~h}$. After that, the solution was extracted with $\mathrm{CH}_{2} \mathrm{Cl}_{2}-\mathrm{H}_{2} \mathrm{O}$, dried with magnesium sulphate $\left(\mathrm{MgSO}_{4}\right)$ and then rotary evaporated. The crude product was purified through column chromatography on silica gel using dichloromethane/petroleum benzine $(1: 1, \mathrm{v} / \mathrm{v})$ as eluent. Pale yellow liquid with yield $78 \%(2.20 \mathrm{~g})$ was obtained. FT-IR $\left(\mathrm{KBr}, 4000-450 \mathrm{~cm}^{-1}\right): 3034(=\mathrm{C}-\mathrm{H}), 2925,2853(\mathrm{C}-\mathrm{H})$, 1101 (C-O). ${ }^{1} \mathrm{H}$ NMR (400 MHz, $\left.\mathrm{CDCl}_{3}\right) \delta$ (p.p.m.): 7.23-6.99 (14H, m), $4.43(2 \mathrm{H}, \mathrm{s}), 3.43(2 \mathrm{H}, \mathrm{t}), 1.85-0.87$ $(15 \mathrm{H}, \mathrm{m})$. Anal. calcd for $\mathrm{C}_{27} \mathrm{H}_{33} \mathrm{NO}: \mathrm{C}, 83.68 ; \mathrm{H}, 8.58 ; \mathrm{N}$, 3.61; O, 4.13; Found: C, 83.63; H, 8.54; N, 3.67\%.

2.3d Synthesis of 3-(octyloxymethyl)-3', $3^{\prime \prime}$-(diformyl)triphenylamine (4): $\mathrm{POCl}_{3}(10 \mathrm{ml})$ and $\mathrm{DMF}(20 \mathrm{ml})$ were mixed in ice bath and then a solution of $\mathbf{3}(2.00 \mathrm{~g}$, $5.16 \mathrm{mmol}$ ) in $20 \mathrm{ml}$ of 1,2-dichloroethane was added dropwise within 20 min. $^{26}$ The mixture was refluxed for $24 \mathrm{~h}$, then poured into ice-water, and neutralized using saturated aqueous $\mathrm{NaOH}$ (adjust the $\mathrm{pH}=6-8$ ). The solution was extracted three times with $\mathrm{CHCl}_{3}$, and then dried using magnesium sulphate overnight. The solvent was removed in vacuo. The residue was purified by flash column chromatography (dichloromethane/petroleum benzine $(4: 1, \mathrm{v} / \mathrm{v})$ as the eluent) to get brown viscous liquid of 4 . Yield $60 \%(1.37 \mathrm{~g})$. FT-IR (KBr, 4000-450 cm $\left.{ }^{-1}\right): 3033(=\mathrm{C}-\mathrm{H}), 2923,2854$ (C-H), 2733 (formyl C-H), $1681(\mathrm{C}=\mathrm{O}), 1076(\mathrm{C}-\mathrm{O}) .{ }^{1} \mathrm{H}$ NMR $\left(400 \mathrm{MHz}, \mathrm{CDCl}_{3}\right) \delta$ (p.p.m.): $9.80(2 \mathrm{H}, \mathrm{s}), 7.68$ $(4 \mathrm{H}, \mathrm{d}), 7.34-7.17(6 \mathrm{H}, \mathrm{m}), 7.01(2 \mathrm{H}, \mathrm{d}), 4.61(2 \mathrm{H}, \mathrm{s}), 3.25$ $(2 \mathrm{H}, \mathrm{s}), 1.75-0.87(15 \mathrm{H}, \mathrm{m})$. Anal. calcd for $\mathrm{C}_{29} \mathrm{H}_{33} \mathrm{NO}_{3}: \mathrm{C}$, 78.52; H, 7.50; N, 3.16; O, 10.82; Found: C, 78.43; H, 7.58; $\mathrm{N}, 3.22 \%$.

2.3e Synthesis of polymer (M): o-Phenylenediamine $(0.50 \mathrm{~g}, 4.63 \mathrm{mmol})$ was dissolved in ethanol $(15 \mathrm{ml})$ with stirring and refluxing. ${ }^{27}$ Then a solution of $4(2.05 \mathrm{~g}$, $4.62 \mathrm{mmol}$ ) in $20 \mathrm{ml}$ of ethanol was added dropwise within $20 \mathrm{~min}$. The mixture was refluxed for $12 \mathrm{~h}$. After being cooled to room temperature, the solvent was evaporated off, and the products were recrystallized from ethanol. The
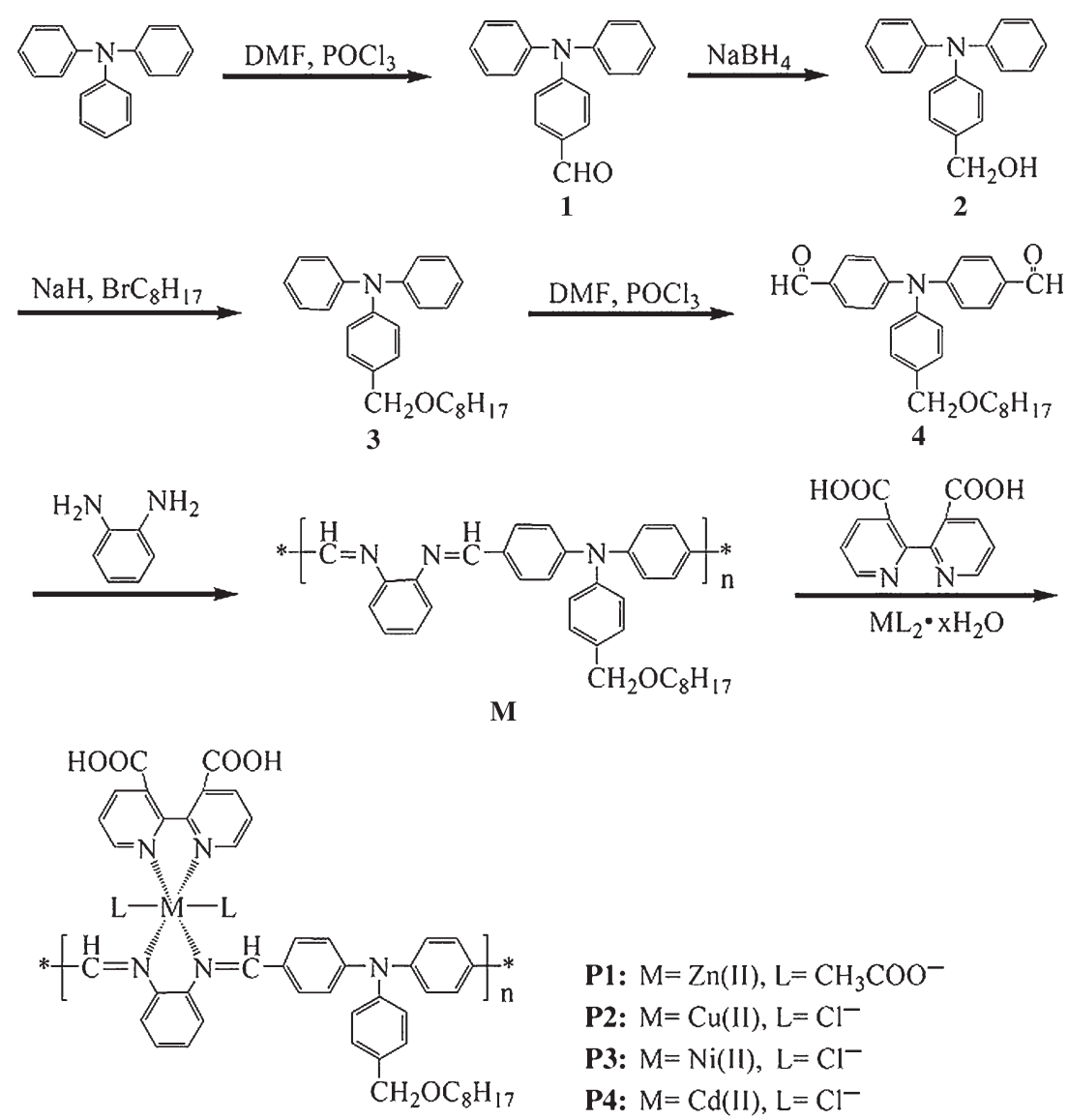

P1: $\mathrm{M}=\mathrm{Zn}(\mathrm{II}), \mathrm{L}=\mathrm{CH}_{3} \mathrm{COO}^{-}$

P2: $\mathrm{M}=\mathrm{Cu}(\mathrm{II}), \mathrm{L}=\mathrm{Cl}^{-}$

P3: $\mathrm{M}=\mathrm{Ni}(\mathrm{II}), \mathrm{L}=\mathrm{Cl}^{-}$

P4: $\mathrm{M}=\mathrm{Cd}(\mathrm{II}), \mathrm{L}=\mathrm{Cl}^{-}$

Scheme 2. Synthesis routes for P1, P2, P3 and P4. 
yield was 56\% (1.43 g). FT-IR (KBr, 4000-450 cm $\left.\mathrm{cm}^{-1}\right): 3386$ $(\mathrm{N}-\mathrm{H}), 3057(=\mathrm{C}-\mathrm{H}), 2924,2858(\mathrm{C}-\mathrm{H}), 1626(\mathrm{C}=\mathrm{N})$. Anal. calcd for $\mathrm{C}_{35} \mathrm{H}_{37} \mathrm{~N}_{3} \mathrm{O}: \mathrm{C}, 81.52 ; \mathrm{H}, 7.23 ; \mathrm{N}, 8.15$; O, 3.10; Found: C, 81.29; H, 7.10; N, 8.23\%. $M_{\mathrm{n}}=8.8 \times$ $10^{3} \mathrm{~g} \mathrm{~mol}^{-1}$, PDI $=1.31$.

$2.3 \mathrm{f}$ Synthesis of polymeric metal complex: The polymeric metal complex P1 was synthesized as per reference to MacLachlan et $a l^{28}$ and Xiao et al. ${ }^{29} \mathbf{M}(1.00 \mathrm{~g}$, $1.93 \mathrm{mmol}$ ) and 2,2'-bipyridine-3,3'-dicarboxylic acid $(0.49 \mathrm{~g}, 2.01 \mathrm{mmol})$ were dissolved together in methanol $(25 \mathrm{~mL})$ with stirring and refluxing. Then a solution of zinc acetate dihydrate $\left[\mathrm{Zn}\left(\mathrm{CH}_{3} \mathrm{COO}\right)_{2} \cdot 2 \mathrm{H}_{2} \mathrm{O}\right](0.44 \mathrm{~g}$, $2.02 \mathrm{mmol}$ ) in $25 \mathrm{~mL}$ of methanol was added dropwise and refluxing continued for $8 \mathrm{~h}$. Precipitated dark yellow solid, filter, washed with methanol and ethanol and dried under vacuum. The yield was $77 \%(1.46 \mathrm{~g})$. FT-IR ( $\mathrm{KBr}, 4000$ $\left.450 \mathrm{~cm}^{-1}\right): 3406(\mathrm{~N}-\mathrm{H}), 3083(=\mathrm{C}-\mathrm{H}), 2933,2851(\mathrm{C}-\mathrm{H})$, $1622(\mathrm{C}=\mathrm{N}), 491(\mathrm{~N}-\mathrm{Zn})$. Anal. calcd for $\mathrm{C}_{51} \mathrm{H}_{51} \mathrm{~N}_{5} \mathrm{O}_{9} \mathrm{Zn}$ : C, 64.93; H, 5.45; N, 7.42; O, 15.26; Zn, 6.93; Found: C, 64.68; H, 5.10; N, 7.33\%. $M_{\mathrm{n}}=13.4 \times 10^{3} \mathrm{~g} \mathrm{~mol}^{-1}$, $\mathrm{PDI}=1.36$.

2.3g Synthesis of polymeric metal complexes (P2), (P3) and (P4): P2, P3 and P4 were synthesized with the similar synthetic method as $\mathbf{P 1}$.

P2: (Yield: $72 \%, 1.29$ g). FT-IR $\left(\mathrm{KBr}, 4000-450 \mathrm{~cm}^{-1}\right)$ : $3414(\mathrm{~N}-\mathrm{H}), 3082(=\mathrm{C}-\mathrm{H}), 2927,2857(\mathrm{C}-\mathrm{H}), 1636(\mathrm{C}=\mathrm{N})$, $507(\mathrm{~N}-\mathrm{Cu})$. Anal. calcd for $\mathrm{C}_{47} \mathrm{H}_{45} \mathrm{Cl}_{2} \mathrm{CuN}_{5} \mathrm{O}_{5}: \mathrm{C}, 63.12 ; \mathrm{H}$, 5.07; Cl, 7.93; Cu, 7.11; N, 7.83; O, 8.94; Found: C, 62.87; $\mathrm{H}, 4.96 ; \mathrm{N}, 7.71 \% . M_{\mathrm{n}}=13.3 \times 10^{3} \mathrm{~g} \mathrm{~mol}^{-1}$, PDI $=1.34$.

P3: (Yield: $75 \%, 1.44 \mathrm{~g})$. FT-IR (KBr, $\left.4000-450 \mathrm{~cm}^{-1}\right)$ : $3396(\mathrm{~N}-\mathrm{H}), 3081(=\mathrm{C}-\mathrm{H}), 2930,2861(\mathrm{C}-\mathrm{H}), 1603(\mathrm{C}=\mathrm{N})$, $512(\mathrm{~N}-\mathrm{Ni})$. Anal. calcd for $\mathrm{C}_{47} \mathrm{H}_{45} \mathrm{Cl}_{2} \mathrm{~N}_{5} \mathrm{NiO}_{5}: \mathrm{C}, 63.46 ; \mathrm{H}$, 5.10; Cl, 7.97; N, 7.87; Ni, 6.60; O, 8.99; Found: C, 63.24; $\mathrm{H}, 4.95 ; \mathrm{N}, 7.80 \% . M_{\mathrm{n}}=11.7 \times 10^{3} \mathrm{~g} \mathrm{~mol}^{-1}$, PDI $=1.39$.

P4: (Yield: $67 \%, 1.28 \mathrm{~g})$. FT-IR (KBr, $\left.4000-450 \mathrm{~cm}^{-1}\right)$ : $3418(\mathrm{~N}-\mathrm{H}), 3081(=\mathrm{C}-\mathrm{H}), 2921,2852(\mathrm{C}-\mathrm{H}), 1623(\mathrm{C}=\mathrm{N})$, $495(\mathrm{~N}-\mathrm{Cd})$. Anal. calcd for $\mathrm{C}_{47} \mathrm{H}_{45} \mathrm{CdCl}_{2} \mathrm{~N}_{5} \mathrm{O}_{5}: \mathrm{C}, 59.85 ; \mathrm{H}$, 4.81; Cd, 11.92; Cl, 7.52; N, 7.43; O, 8.48; Found: C, 59.77; $\mathrm{H}, 4.72 ; \mathrm{N}, 7.34 \% . M_{\mathrm{n}}=14.2 \times 10^{3} \mathrm{~g} \mathrm{~mol}^{-1}, \mathrm{PDI}=1.33$.

\section{Results and discussion}

\subsection{Synthesis and characterization}

The detailed synthetic routes of the four polymeric metal complexes (P1-P4) are shown in scheme 2, and the four polymers P1, P2, P3 and P4 were synthesized by the Schiff base reaction ${ }^{30}$ and coordination reaction. ${ }^{31}$ The four assynthesized polymers were readily dissolved in common organic solvents such as DMF and DMSO at room temperature. However, in the other solvents they exhibit a poor solubility, such as in chloroform and dichloromethane.
Figure 1 shows the ${ }^{1} \mathrm{H}$ NMR spectra of the 3(octyloxymethyl)- $3^{\prime}, 3^{\prime \prime}$-(diformyl)triphenylamine (4). The formyl proton peaks appeared at 9.80 p.p.m., the vinyl proton peaks appeared at around 7.68-7.01 p.p.m., the proton of methylene locating at the a position is observed at 4.61 p.p.m., and the protons of octyl appeared at 3.250.87 p.p.m. The ${ }^{1} \mathrm{H}$ NMR shows that monomer was synthesized successfully.

The IR spectra of the polymer $\mathbf{M}$ and the polymeric metal complex (P1-P4) are shown in figure 2. As for the polymer $\mathbf{M}$, absorption peaks at $1626 \mathrm{~cm}^{-1}$ is due to $\mathrm{C}=\mathrm{N}$ bond stretching vibration, the absorption peaks at $3386 \mathrm{~cm}^{-1}$ are the characteristic absorption peaks of the amino-group stretching vibration, and the peak at $2924,2858 \mathrm{~cm}^{-1}$ is $\mathrm{C}-\mathrm{H}$ bond stretching vibration absorption peak, the peak at $3057 \mathrm{~cm}^{-1}$ is $=\mathrm{C}-\mathrm{H}$ bond stretching vibration absorption peak. From figure 2, the peaks of 491, 507, 512 and $495 \mathrm{~cm}^{-1}$

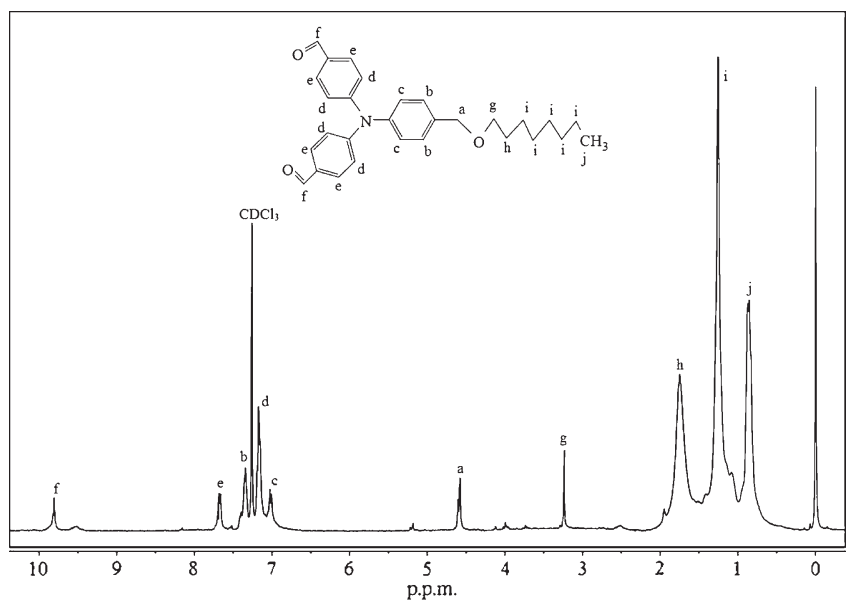

Figure 1. ${ }^{1} \mathrm{H}$ NMR spectra of the 3-(octyloxymethyl)- $3^{\prime}, 3^{\prime \prime}-$ (diformyl)triphenylamine (4) in $\mathrm{CDCl}_{3}$ solution.

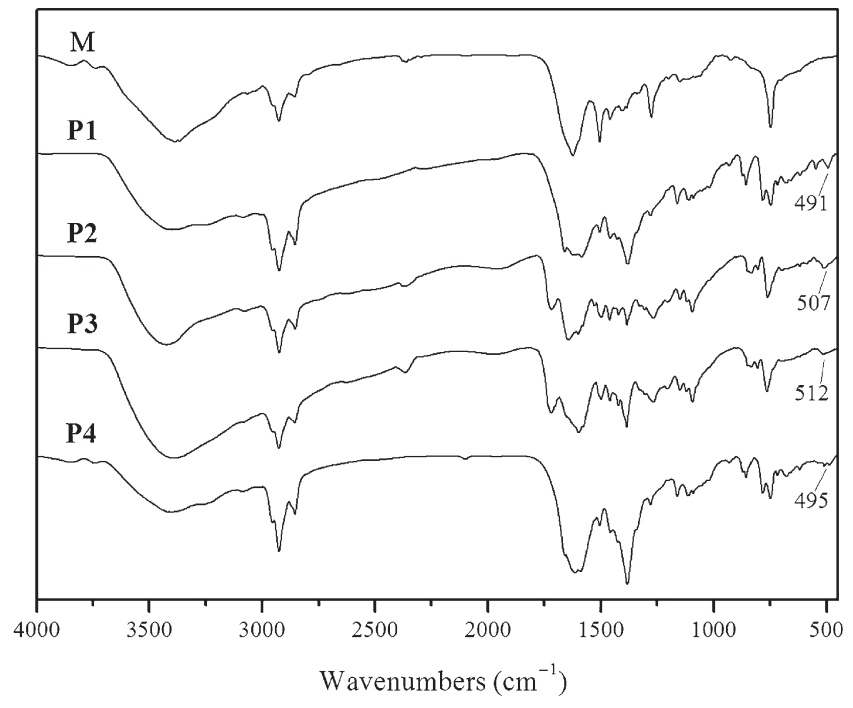

Figure 2. FT-IR spectra of $\mathbf{M}$ and polymeric metal complexes (P1, P2, P3 and P4). 
are due to $\mathrm{N}-\mathrm{M}$ bond stretching vibration of the polymeric metal complex (P1, P2, P3 and P4), respectively. ${ }^{32}$ Combining with the results of elemental analysis, we can conclude that metal $\mathrm{Zn}^{2+}, \mathrm{Cu}^{2+}, \mathrm{Ni}^{2+}$ and $\mathrm{Cd}^{2+}$ has been successfully coordinated with the polymer $\mathbf{M}$, namely the polymeric metal complex (P1, P2, P3 and P4, respectively) have been successfully synthesized. Due to the introduction of donor unit and extension of the conjugated system, the stretching vibration absorption peaks of $\mathrm{C}=\mathrm{N}$ and $\mathrm{N}-\mathrm{M}$ bond of all the target polymers stretching vibration absorption peaks have some degree of red shift, which can prove that the target products have been successfully synthesized combined with the GPC test results (table 1) and elemental analysis results.

GPC study results of all the target polymers are shown in table 1. The number-average-molecular weight of P1, P2, P3 and $\mathbf{P 4}$ is $13.4,13.3,11.7$ and $14.2 \mathrm{~kg} \mathrm{~mol}^{-1}$, and the unit of them is 14, 15, 13 and 15, respectively. All the PDI of polymeric metal complexes are relatively wide (P1, P2, P3 and P4: 1.36, 1.34, 1.39 and 1.33, respectively).

\subsection{Optical properties}

Figures 3 and 4 give the UV-Vis and normalized PL spectra of the polymeric metal complexes P1-P4 $\left(10^{-5} \mathrm{M}\right.$ in DMF solution), respectively, and the corresponding data are summarized in table 2.

In figure 3, the maximum absorption of P1, P2, P3 and $\mathbf{P 4}$ are at 391, 399, 384 and $405 \mathrm{~nm}$, respectively, and this absorption bands result from intramolecular charge transfer between the electron acceptor metal-o-Phenylenediamine unit and the electron donating alkoxy triphenylamine. Those polymers have very weak shoulder absorption peak in the band 430-470 nm, which is due to the charge transition of the o-Phenylenediamine derivatives and metal ions in the polymer.

The normalized PL spectra of P1-P4 in DMF solution are shown in figure 4 , the excitation wavelengths were set according to the absorption peak of UV-Vis spectrum, and the corresponding optical data are also listed in table 2. It can

Table 1. Molecular weights and thermal properties of the polymeric metal complexes.

\begin{tabular}{lcccccc}
\hline Polymer & $\begin{array}{c}M_{\mathrm{n}}{ }^{\mathrm{a}} \\
\left(\times 10^{3}\right)\end{array}$ & $\begin{array}{c}M_{\mathrm{w}}{ }^{\mathrm{a}} \\
\left(\times 10^{3}\right)\end{array}$ & $N$ & PDI & $\begin{array}{c}T_{\mathrm{g}}{ }^{\mathrm{b}} \\
\left({ }^{\circ} \mathrm{C}\right)\end{array}$ & $\begin{array}{c}T_{\mathrm{d}}{ }^{\mathrm{d}} \\
\left({ }^{\circ} \mathrm{C}\right)\end{array}$ \\
\hline P1 & 13.4 & 18.2 & 14 & 1.36 & 130 & 317 \\
P2 & 13.3 & 17.8 & 15 & 1.34 & 126 & 298 \\
P3 & 11.7 & 16.3 & 13 & 1.39 & 121 & 269 \\
P4 & 14.2 & 18.9 & 15 & 1.33 & 123 & 287 \\
\hline
\end{tabular}

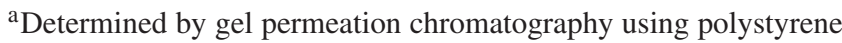
as standard.

${ }^{\mathrm{b}}$ Determined by DSC with a heating rate of $10^{\circ} \mathrm{C} \min ^{-1}$ under nitrogen.

${ }^{\mathrm{c}}$ The temperature at $5 \%$ weight loss under nitrogen. be seen that the PL peaks of P1, P2, P3 and P4 are at 463, 485, 449 and $483 \mathrm{~nm}$, respectively, which can be attributed to the $\pi-\pi *$ transition of intraligand.

\subsection{Thermal stability}

As an important part of DSSC, the dye should have good stability that can increase the thermal stability of photovoltaic devices. Therefore, the thermal stability study has important implications for DSSC. TGA and DSC were selected to study the thermal stability of the target product, and the TGA is used to test the target thermal decomposition temperature ( $T_{\mathrm{d}}: 5 \%$ weight loss temperature), while the DSC is used to test the target glass-transition temperature $\left(T_{\mathrm{g}}\right)$. The corresponding data are listed in table 1. The TGA results (figure 5) show the $T_{\mathrm{d}}$ of the four polymeric metal complexes (P1, P2, P3 and P4) are at temperatures of 317, 298, 269 and $287^{\circ} \mathrm{C}$ in nitrogen, respectively, which means all of

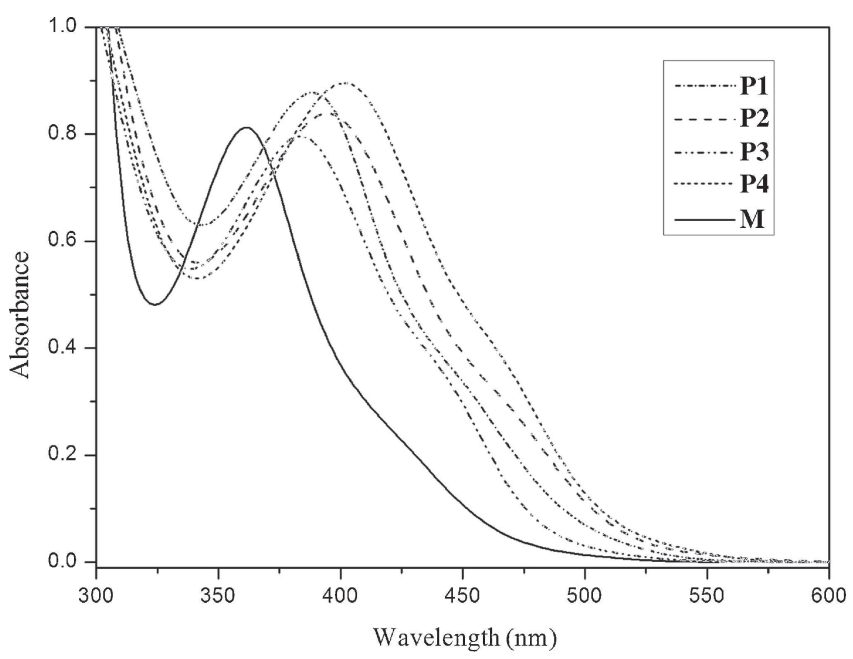

Figure 3. UV-Vis absorption spectra of $\mathbf{M}$ and polymeric metal complexes (P1, P2, P3 and P4) in DMF solution.

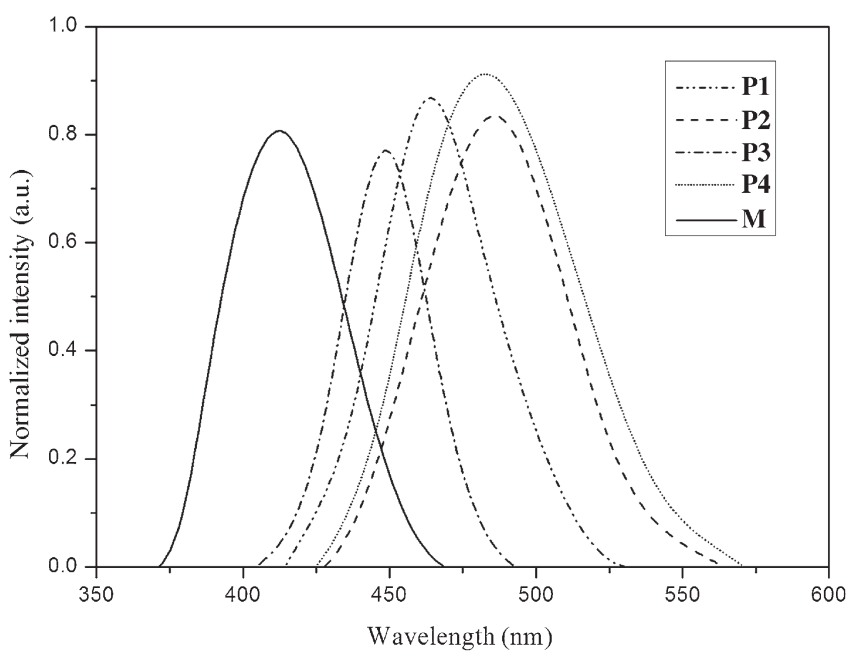

Figure 4. PL spectra of $\mathbf{M}$ and the four polymeric metal complexes (P1-P4) in DMF solution. 
Table 2. Optical and electrochemical properties of the polymeric metal complexes.

\begin{tabular}{lllllllll}
\hline & $\begin{array}{c}\lambda_{\mathrm{a}, \max }{ }^{\mathrm{a}} \\
{ }^{\mathrm{a}}\end{array}$ & & $\begin{array}{c}E_{\mathrm{Ox}} \\
\lambda_{\mathrm{a}, \text { onset }}\end{array}$ & $\begin{array}{c}E_{\text {red }} \\
\lambda_{\mathrm{p}, \max }{ }^{\mathrm{C}}\end{array}$ & $\begin{array}{c}\text { HOMO } \\
(\mathrm{V})^{\mathrm{c}}\end{array}$ & $\begin{array}{c}\text { LUMO } \\
(\mathrm{eV})\end{array}$ & $\begin{array}{c}E_{\mathrm{g}, \mathrm{EC}} \\
(\mathrm{eV})\end{array}$ & $(\mathrm{eV})^{\mathrm{d}}$ \\
\hline P1 & 391,513 & 463 & 1.22 & -1.01 & -5.62 & -3.39 & 2.23 \\
P2 & 399,521 & 485 & 1.19 & -1.06 & -5.59 & -3.34 & 2.25 \\
P3 & 384,498 & 449 & 1.23 & -1.11 & -5.63 & -3.29 & 2.34 \\
P4 & 405,534 & 483 & 1.21 & -1.08 & -5.61 & -3.32 & 2.29 \\
\hline
\end{tabular}

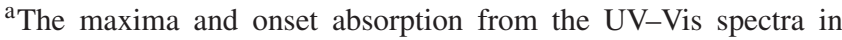
DMF solution.

${ }^{\mathrm{b}}$ The PL maxima in DMF solution.

${ }^{\mathrm{c}}$ Values determined by cyclic voltammetry.

${ }^{\mathrm{d}}$ Electrochemical bandgap estimated from HOMO and LUMO.

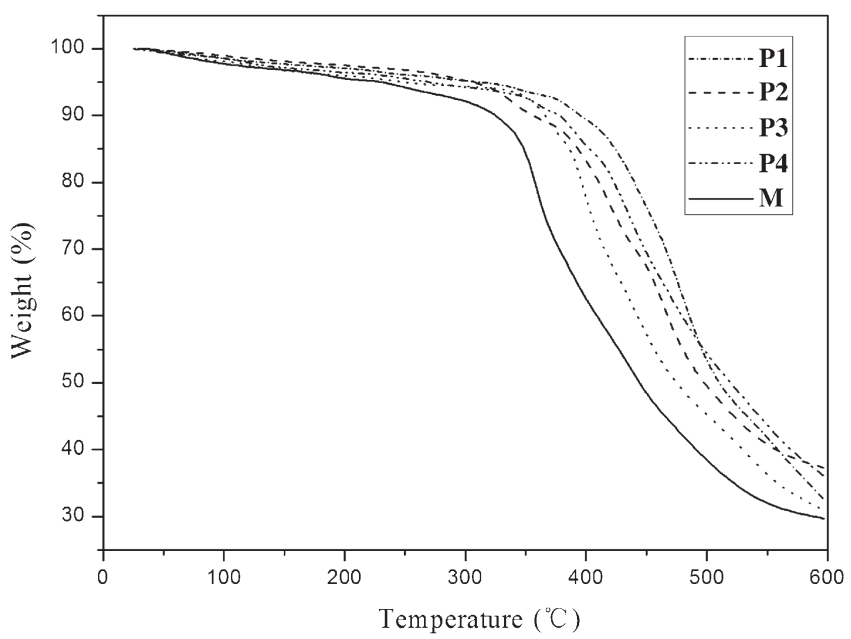

Figure 5. TGA curves of P1-P4 with a heating rate of $10^{\circ} \mathrm{C}$ $\min ^{-1}$ under nitrogen atmosphere.

them are at steady state. ${ }^{33}$ Synchronously, from the data of table 1, we can see that the $T_{\mathrm{g}}$ of the four polymeric metal complexes (P1, P2, P3 and P4) were at 130, 126, 121 and $123^{\circ} \mathrm{C}$, respectively, and no crystallization or melting peaks were detected, indicating that the polymers are amorphous. There is no fixed melting point, which means that all of target products are amorphous structure, that this kind of structure might not conducive to use in organic solar cells. ${ }^{34}$ The high glass-transition temperature of them shows that these kind of materials have great application prospects in improving the stability of the DSSCs, which can prevent morphological change, deformation and degradation of the active layer by current-induced heat during operation of the photovoltaic polymers.

\subsection{Electrochemical properties}

Electronic energy level is one of the most important properties for organic materials used in solar cells. Figure 6 shows the cyclic voltammograms of P1-P4. The cyclic

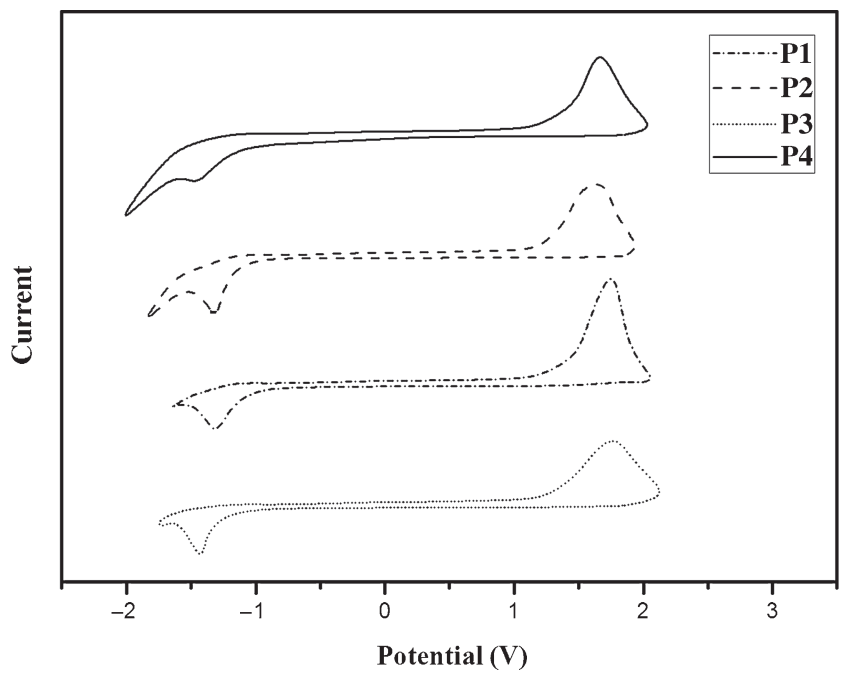

Figure 6. Cyclic voltammograms for P1-P4 in $\mathrm{DMF} / 0.1 \mathrm{M}$ $\left[\mathrm{Bu}_{4} \mathrm{~N}\right] \mathrm{BF}_{4}$ at $50 \mathrm{mV} \mathrm{s}^{-1}$.

voltammetry of polymeric metal complexes were measured in DMF containing $\left[\mathrm{Bu}_{4} \mathrm{~N}\right] \mathrm{BF}_{4}(\mathrm{Bu}=$ butyl) as supporting electrolyte and SCE as reference electrode at a scan rate of $50 \mathrm{mV} \mathrm{s}^{-1}$. The LUMO and HOMO energy levels of the dyes are crucial property for materials used in DSSCs. From the onset oxidation potentials $\left(E_{\mathrm{ox}}\right)$ and the onset reduction potentials $\left(E_{\text {red }}\right)$ of the polymers, HOMO and LUMO energy levels as well as the energy gap of the polymers were calculated according to the following equations. ${ }^{35}$

$$
\begin{aligned}
& \text { HOMO }=-\mathrm{e}\left(E_{\mathrm{ox}}+4.40\right)(\mathrm{eV}), \\
& \text { LUMO }=-\mathrm{e}\left(E_{\text {red }}+4.40\right)(\mathrm{eV}), \\
& E_{\mathrm{g}}=\text { HOMO - LUMO }
\end{aligned}
$$

The values obtained are listed in table 2. The HOMO energy level of P1, P2, P3 and P4 are calculated to be $-5.62,-5.59,-5.63$ and $-5.61 \mathrm{eV}$, respectively, which are lower than the standard potential of the $I_{3}^{-} / I^{-}$redox couple $(-4.94 \mathrm{eV} v s$. NHE). This indicates that sufficient driving forces for the regeneration of the oxidized dyes are available. Their corresponding LUMO energy level are $-3.39,-3.34$, -3.29 and $-3.32 \mathrm{eV}$, respectively, and they are sufficiently higher than the conduction band edge of $\mathrm{TiO}_{2}(-4.04 \mathrm{eV} v$ s. NHE), ${ }^{36}$ which demonstrate that effective electron transfer from the excited dye to the $\mathrm{TiO}_{2}$ is ensured.

\subsection{Photovoltaic properties}

DSSC devices based on these four polymeric metal complexes were fabricated and tested under the illumination of AM $1.5 \mathrm{G}, 100 \mathrm{~mW} \mathrm{~cm}{ }^{-2}$ for solar cell applications. Following our conventional practice for these polymeric metal complexes using solution process, ${ }^{37,38}$ the active layers were spin-coated from their DMF solutions. The incident photonto-electron conversion efficiency (IPCE) curves and currentvoltage curves $(J-V$ curves) of the four polymeric metal 


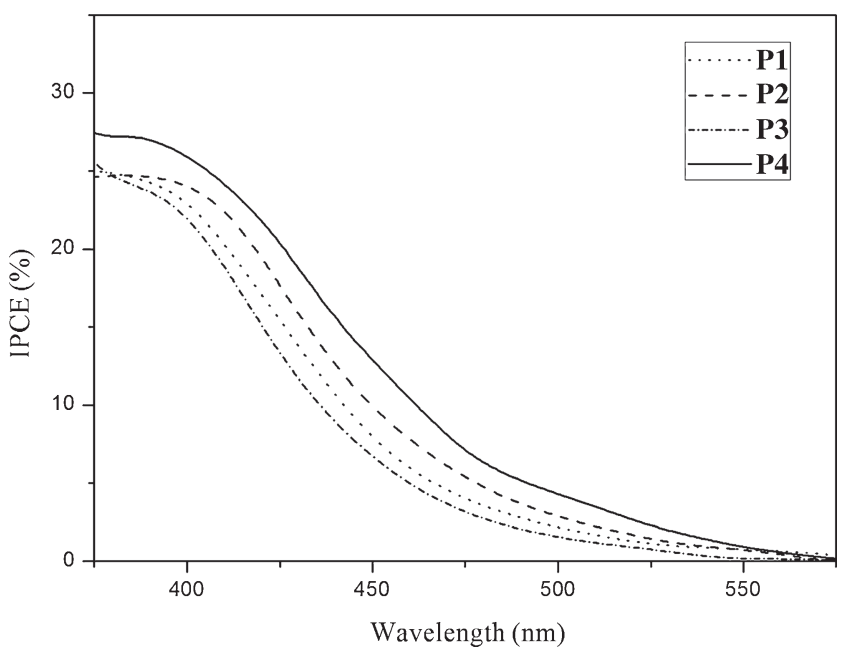

Figure 7. IPCE plots for the DSSC based on the four polymeric metal complexes (P1-P4) on the ITO glass.

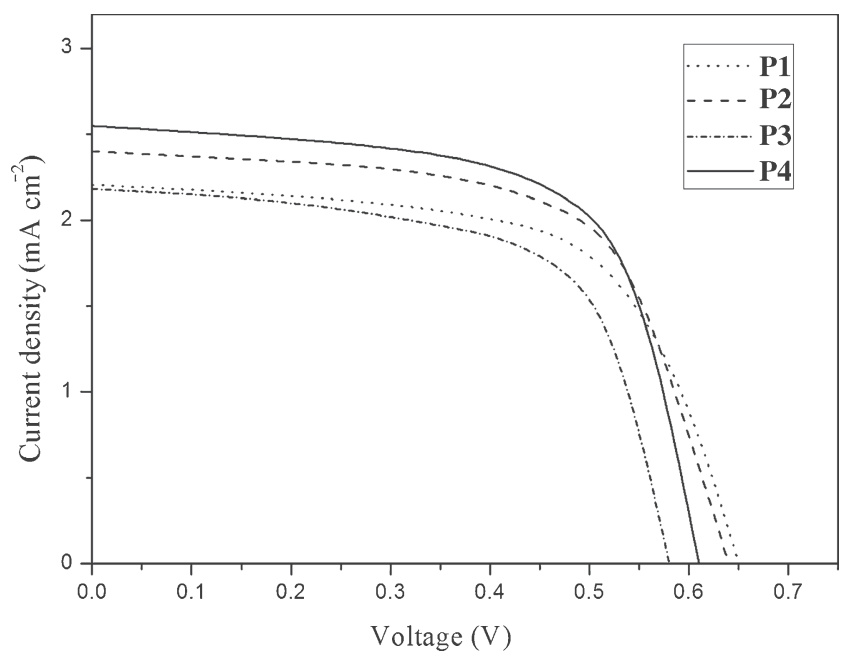

Figure 8. $J-V$ curves of DSSCs based on dyes (P1-P4) under the illumination of AM 1.5, $100 \mathrm{~mW} \mathrm{~cm}^{-2}$.

complexes are shown in figures 7 and 8, and the open-circuit voltage $\left(V_{\mathrm{oc}}\right)$, fill factor $(\mathrm{FF})$, short-circuit current $\left(J_{\mathrm{sc}}\right)$ and other relevant data are listed in table 3.

Figure 7 shows IPCE of the DSSC devices based on four polymeric metal complexes (P1-P4). From the figure 7, the IPCE values of the dye P1, P2, P3 and P4 reach to 22.9, 24.2, 22.1 and $26.1 \%$, respectively, around the band $400 \mathrm{~nm}$. Though dye $\mathbf{P} \mathbf{4}$ has the maximum IPCE among the four dyes, the results are not compared with that of the traditional ruthenium dye, which is probably the cause by low charge collection efficiency. ${ }^{39}$

The $J-V$ curves are reported in figure 8 and the corresponding photovoltaic performance is summarized in table 3 . From the data of table 3 , we can see that the short-circuit current $\left(J_{\mathrm{sc}}\right)$ of the P1, P2, P3 and P4 is 2.20, 2.40, 2.18 and $2.55 \mathrm{~mA} \mathrm{~cm}^{-2}$, respectively. The reasons for $\mathbf{P} 4$ to have the highest short-circuit current in these four polymeric metal
Table 3. Photovoltaic parameters of devices with sensitizers P1-P4 in DSSCs at full sunlight (AM 1.5 G, $100 \mathrm{~mW} \mathrm{~cm}^{-2}$ ).

\begin{tabular}{lccccc}
\hline Polymer & Solvent & $J_{\mathrm{sc}}\left(\mathrm{mA} \mathrm{cm}^{-2}\right)$ & $V_{\mathrm{oc}}(\mathrm{V})$ & $\mathrm{FF}(\%)$ & $\eta(\%)$ \\
\hline P1 & DMF & 2.20 & 0.65 & 67.72 & 0.97 \\
P2 & DMF & 2.40 & 0.64 & 65.80 & 1.01 \\
P3 & DMF & 2.18 & 0.58 & 68.03 & 0.86 \\
P4 & DMF & 2.55 & 0.61 & 70.14 & 1.09 \\
\hline
\end{tabular}

complexes are that $\mathbf{P 4}$ possess a larger coordinated metal ion and owns higher IPCE, which cause high charge separation and transportation efficiency. The open circuit voltage $\left(V_{\mathrm{oc}}\right)$ of P1, P2, P3 and P4 is $0.65,0.64,0.58$ and $0.61 \mathrm{~V}$, respectively. It is clearly shown that $\mathbf{P 1}$ with the highest $V_{\mathrm{oc}}$, the reason can be ascribe to the LUMO energy level of P1 $(-3.39 \mathrm{eV})$, is lowest among the polymeric metal complexes and that make $\mathbf{P 1}$ to be a better match with $\mathrm{TiO}_{2}$ in energy level field.

The power conversion efficiency $(\eta)$ based on P1, P2, P3 and $\mathbf{P} 4$ reached $0.97,1.01,0.86$ and $1.09 \%$, respectively.

\section{Conclusions}

In this paper, four novel polymeric metal complexes were functionally designed, synthesized and characterized by IR, ${ }^{1} \mathrm{H}$ NMR, GPC, elemental analysis and so on. Their photovoltaic performances in DSSCs were also investigated. The results show the following: (1) All the four polymeric metal complexes exhibited some photovoltaic performance, and the highest photoelectric conversion efficiency of cadmium polymeric metal complexes (P4) reached $1.09 \%$ $\left(J_{\mathrm{sc}}=2.55 \mathrm{~mA} \mathrm{~cm}^{-2}, V_{\mathrm{oc}}=0.61 \mathrm{~V}\right.$, and FF $\left.=70.14\right)$ under simulate AM 1.5 G solar irradiation. (2) The introductions of polymerized $\pi$-system and metal complexes have broadened the absorption spectra and improve the thermal performance. (3) These polymeric metal complexes have higher $V_{\text {oc }}$ and FF.

Mostly, the metal ion that we have introduced into complexes favour the 'push-pull' type dye absorption and hence influence the efficiency of DSSC sensitizers. It is clear that the four sensitizers have similar conformation, however, DSSCs based on them show that the energy conversion efficiency as well as optical performance parameters of $\mathbf{P 1}$ and $\mathbf{P 4}$ are preceded by $\mathbf{P 3}$, which demonstrate that polymer using metal ion with $d^{10}$ electronic configuration is better than that of with $d^{8}$ electronic arrangement structure. This result is consistent with our previous observation of ultraviolet absorption spectrum. All the LUMO energy level of the complexes are higher than the LUMO level of $\mathrm{TiO}_{2}$, which makes the electrons transfer to $\mathrm{TiO}_{2}$ smoothly.

Furthermore, in order to further improve the efficiency of DSSCs, we need to find or design a sensitizer that can absorb in the near-IR region as well as over the entire visible region of the solar spectrum and could maintain a sufficient thermodynamic driving force for both electron injection and sensitizer regeneration processes. The rare metal ions were 
replayed by common metal ions, which will make the synthesis of novel polymeric metal complexes cheaper and provide a new path for the study and design of the new practical dye sensitizers.

\section{Acknowledgements}

This work was financially supported by the Open Project Program of Key Laboratory of Environmentally Friendly Chemistry and Applications of Ministry of Education, China (no. 09HJYH10).

\section{References}

1. Erten-Ela S, Yilmaz M D, Icli B, Dede Y, Icli S and Akkaya E U 2008 Org. Lett. 103299

2. Wang P, Klein C, Moser J-E, Humphry-Baker R, Cevey-Ha N-L, Charvet R, Comte P, Zakeeruddin S M and Gra1tzel M 2004 J. Phys. Chem. B 10817553

3. Fakis M, Stathatos E, Tsigaridas G, Giannetas V and Persephonis P 2011 J. Phys. Chem. C 11513429

4. Mende L S, Bach U, Baker R H, Horiuchi T, Miura H, Ito S, Uchida S and Gratzel M 2005 Adv. Mater. 17813

5. Kitamura T, Ikeda M, Shigaki K, Inoue T, Anderson N A, Ai X, Lian T and Yanagida S 2004 Chem. Mater. 161806

6. Nazeeruddin K, Baker R H, Officer D L, Campbell W M, Burrell A K and Gratzel M 2004 Langmuir 206514

7. Allegrucci A, Lewcenko N A, Mozer A J, Dennany L, Wagner P, Officer D L, Sunahara K, Moric S and Spiccia L 2009 Energy Environ. Sci. 21069

8. Fischer M K R, Lopez-Duarte I, Wienk M M, Martınez-Diaz M V, Janssen R A, Bauerle P and Torres T 2009 J. Am. Chem. Soc. 1318669

9. Dai Q and Rabani J 2002 New J. Chem. 26421

10. Lai W H, Su H Y and Teoh G L 2008 J. Photochem. Photobiol. A 195307

11. Caballero R, Barea E M, Fabregat-Santiago F, de la Cruz P, Marquez L, Langa F and Bisquert J 2008 J. Phys. Chem. C 112 18623

12. Lee C, Yum J-H, Choi H, Kang S O, Ko J, Humphry-Baker R, Grätzel M and Nazeeruddin Md K 2008 Inorg. Chem. 47 2267

13. Qin P, Wiberg J, Gibson E A, Linder M, Li L, Brinck T, Hagfeldt A, Albinsson B and Sun L C 2010 J. Phys. Chem. C 1144738

14. Cao D, Peng J, Hong Y, Fang X, Wang L and Meier H 2011 Org. Lett. 131610

15. Ito S, Miura H, Uchida S, Takata M, Sumioka K, Liska P, Comte P, Péchy P and Grätzel M 2008 Chem. Commun. 5194
16. Grisorio R, Mastrorilli P, Suranna G P, Cosma P, Marco L D, Manca M and Gigli G 2011 J. Polym. Sci. Part A: Polym. Chem. 49842

17. Chen B S, Chen D Y, Chen C L, Hsu C W, Hsu H C, Wu K L, Liu S H, Chou P T and Chi Y 2011 J. Mater. Chem. 211937

18. Fang Z, Eshbaugh A A and Schanze K S 2011 J. Am. Chem. Soc. 1333063

19. Yang Y S, Kim H D, Ryu J H, Kim K K, Park S S and Ahn K S 2011 Synth. Met. 161850

20. Ooyama Y, Inoue S, Nagano T, Kushimoto K, Ohshita J, Imae I, Komaguchi K and Harima Y 2011 Angew. Chem. (Int. Ed.) 507429

21. Srinivas K, Kumar C R, Reddy M A, Bhanuprakash K, Rao V J and Giribabu L 2011 Synth. Met. 16196

22. Williams K A, Boydston A J and Bielawski C W 2007 Chem. Soc. Rev. 36729

23. Leung A C W, Chong J H, Patrick B O and MacLachlan M J 2003 Macromolecules 365051

24. Wang X-M, Zhou Y-F, Yu W-T, Wang C, Fang Q, Jiang M-H, Lei H and Wang H-Z 2000 J. Mater. Chem. 102698

25. Lee J, Jung B-J, Lee J-I, Chu H Y, Do L-M and Shim H-K 2002 J. Mater. Chem. 123494

26. Liu B, Zhang Q, Ding H, Hu G, Du Y, Wang C, Wu J, Li S, Zhou H, Yang J and Tian Y 2012 Dyes Pigments 95149

27. Neuvonen K, Fulop F, Neuvonen H, Koch A, Kleinpeter E and Pihlaja K 2003 J. Org. Chem. 682151

28. MacLachlan M J, Park M K and Thompson L K 1996 Inorg. Chem. 355492

29. Xiao L, Liu Y, Xiu Q, Zhang L, Guo L, Zhang H and Zhong C 2010 J. Polym. Sci.: Part A: Polym. Chem. 481943

30. Guzen K P, Guarezemini A S, Orfao A T G, Cella R, Pereira C M P and Stefani H A 2007 Tetrahedron Lett. 481845

31. Guo L, Deng J, Zhang L, Xiu Q, Wen G and Zhong C 2012 Dyes Pigments 921062

32. Liu Y, Xiu Q, Xiao L, Huang H, Guo L, Zhang L, Zhang H, Tan S and Zhong C 2011a Polym. Adv. Technol. 22 2583

33. Jin S H, Park H J, Kim J Y, Lee K, Lee S P, Moon D K, Lee H J and Gal Y S 2003 Macromolecules 357532

34. Sun S S and Sariciftci N S (Eds.) 2005 Organic photovoltaics: mechanisms, materials and devices (Boca Raton, FL: CRC)

35. Li X Z, Zeng W J, Zhang Y, Hou Q, Yang W and Cao Y 2005 Eur. Polym. J. 412923

36. Zhang L, Cole J M, Waddell P G, Low K S and Liu X 2013 ACS Sust. Chem. Eng. 11440

37. Liu Y, Wan X, Wang F, Zhou J, Long G, Tian J, You J, Yang Y and Chen Y 2011b Adv. Energy Mater. 1771

38. He G, Li Z, Wan X, Liu Y, Zhou J, Long G, Zhang M and Chen Y 2012 J. Mater. Chem. 229173

39. Fischer M K R, Wenger S, Wang M, Mishra A, Zakeeuddin S M, Grätzel M and Bäuerle P 2010 Chem. Mater. 221836 